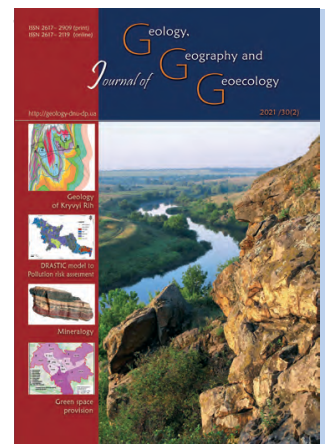

Journal of Geology,

\title{
Long term hydrological and environmental monitoring of the Stryi River using remote sensing data and GIS technologies
}

\author{
Khrystyna V. Burshtynska ${ }^{1}$, Svitlana S. Kokhan ${ }^{2}$, Andrii V. Babushka ${ }^{1}$, Ihor M. Bubniak ${ }^{1}$, Volodymyr M. Shevchuk ${ }^{1}$ \\ ${ }^{1}$ Lviv Polytechnic National University, Lviv, Ukraine, andriy.babushka@gmail.com \\ ${ }^{2}$ National University of Life and Environmental Sciences of Ukraine, Kyiv, Ukraine
}

Received: 14.12 .2020

Received in revised form: 06.03 .2021

Accepted: 26.03.2021

\begin{abstract}
The proposed research sets the task of conducting monitoring aimed at determining the horizontal displacements of the channel of the Stryi River the largest right-bank tributary of the Dniester River. For this purpose, the river was zoned according to morphometric and hydrological characteristics. Three parts were identified, namely
\end{abstract} highland, piedmont and lowland ones, which radically vary in the nature of the flow and the amount of the displacement. The main research purpose consists in analyzing the impact of anthropogenic factors on the hydrological regime of the Stryi River, as well as studying the effect of the Ukrainian Carpathian Foredeep (UCF) and the Stryi Deep on the mode of horizontal displacements. The research object is processes occurring within the Stryi River channel. Considering main natural factors affecting the channel's horizontal displacements, special attention is paid to the geological and sedimentological structures located in the region where the Stryi River and its tributaries flow; among the anthropogenic factors, deforestation and the extraction of building materials from the river channel are highlighted. Topographic, geological, soil maps and satellite images of various periods uploaded into ArcGIS software allowed us to monitor displacements observed for as long as 140 years ago. To monitoring the Stryi River channel displacements, such materials as topographic maps scaled 1: 75000 (Austrian period - 1874), 1: 100000 (Polish period - 1933, Soviet period - 1990); satellite images of Sentinel-2 (2019 and 2020 (after the flood)); a map of Quaternary sediments and a soil map scaled 1: 200000 were used. The Stryi River flows between two structures, i.e. the Skybovi Carpathians and the UCF. The right-bank tributaries (Bystrytsia, Limnitsia, Stryi, etc.), which begin in the Carpathians, cross the outer and inner boundaries of the UCF and are characterized by the stable river channel in its mountainous part, multi-braided in its piedmont part, as well as perennial and significant meandering within the Pre-Carpathian region. Lithological deposits have a significant impact at the mouth of the Stryi River. According to the research study results, displacements of up to $1,350 \mathrm{~m}$ are measured in this area. The research includes an analysis of the influence of geological and sedimentological structures on the Stryi River displacement and the nature of its flow. It has been established that deforestation in the river basin, as well as unauthorized extraction of gravel materials, creates a significant environmental problem in this region. The results of monitoring of the channel deformation processes should be taken into account when solving problems related to river channel processes, namely the construction of hydraulic structures, the design of power transmission networks crossing rivers, the development of gas pipelines, the identification of hazardous flooding zones, the determination of consequences of destruction after floods, the establishment of boundaries of water protection zones, the management of recreational activities, monitoring of border lands and the establishment of an interstate border along rivers.

Key words: geological structures, monitoring, topographic maps, satellite images, Ukrainian Carpathians

\section{Гідролого-екологічний моніторинг річки Стрий за довгостроковий період з використан- ням матеріалів Д33 та ГІС-технологій}

\author{
Бурштинська Х. В. ${ }^{1}$, Кохан С. С. ${ }^{2}$, Бабушка А. В. ${ }^{1}$, Бубняк I. M. ${ }^{1}$, Шевчук В. M. ${ }^{1}$ \\ ${ }^{1}$ Національний університет “Львівська політехніка”, м.Львів, Украӥна, andriy.babushka@gmail.com \\ ${ }^{2}$ Національний університет біоресурсів та природокористування Украӥни, м.Киї, Україна
}

Анотація. В запропонованому дослідженні поставлено завдання реалізації моніторингу з визначення горизонтальних зміщень русла річки Стрий, найбільшої правобережної притоки Дністра. 3 цією метою здійснено районування річки за морфометричними та гідрологічними характеристиками. Виділено три частини: гірську, передгірську і рівнинну, які кардинально відрізняються характером протікання і величинами зміщень. Мета роботи - проаналізувати вплив антропогенних чинників на гідрологічний режим річки Стрий, а також дослідити вплив Передкарпатського та Стрийського прогинів на характер горизонтальних зміщень. Об'єктом цього дослідження є руслові процеси річки Стрий. Розглядаючи основні 
природні чинники, що впливають на горизонтальні зміщення русла, особливу увагу надано геологічним та сегментологічним структурам у регіоні, де протікає річка Стрий та їі притоки, серед антропогенних виділено вирубку лісів та забір будівельних матеріалів з русла річки. Застосовуючи програмний пакет ArcGIS, здійснено моніторинг зміщень протягом більше 140 років, використовуючи топографічні, геологічні, грунтові карти та космічні зображення різних періодів. Для моніторингу зміщень русла Стрий використано топографічні карти в масштабах 1:75000 (австрійський період - 1874р.), 1:100000 (польський період - 1933, радянський період - 1990р.); космічні зображення Sentinel2 (2019 та 2020 р. (після паводку)); карту четвертинних відкладів та грунтову карту масштабу 1:200000. Річка Стрий протікає в межах дії двох структур - Скибових Карпат та Передкарпатського прогину. Правобережні притоки (Бистриця, Лімниця, Стрий та ін.), які починаються в Карпатах, перетинають зовнішні та внутрішні межі Передкарпатського прогину і характеризуються стійкістю русла річки в гірській частині, багаторукавністю в передгірській частині та багаторічним і значним меандруванням у межах Прикарпаття. Седиментогенні родовища мають значний вплив в гирлі річки Стрий. За результатами дослідження в цій ділянці зміщення досягають 1350 м. Дослідження включає аналіз впливу геологічних та сегментологічних структур на зміщення річки Стрий та характер ії протікання. Встановлено, що вирубування лісів в басейні річки, як і несанкціонований відбір гравійних матеріалів створює значну екологічну проблему в регіоні. Результати моніторингу процесів деформації русла необхідно враховувати при вирішенні завдань, пов'язаних з русловими процесами річки, а саме: будівництві гідротехнічних споруд, проектуванні мереж електропередачі при перетині річок, розвитку газопроводів, визначенні небезпечних зон затоплення, визначенні наслідків руйнування після повеней, встановленні меж водоохоронних зон, управлінні відпочинковою діяльністю, моніторингу прикордонних земель та встановленні міждержавного кордону вздовж річок.

Ключові слова: геологічні структури, моніторинг, топографічні карти, космічні зображення

\section{Introduction}

Like the blood vessels of an organism, rivers have become a life-giving force of the entire living world on the Earth. On the one hand river channels are subject to the objective laws of channel formation, and on the other hand, they undergo constant changes resulting from human activity. The study of horizontal reshaping of river channels makes it possible to understand the mechanism of their development more precisely. This applies to a plethora of national economy sectors, the functioning of which is associated with the use of riverbeds and floodplains. In particular, it is impossible to reliably build and operate hydraulic structures, design river crossings, and develop floodplain lands without taking into account the development of channel deformations (both vertical and horizontal). When making artificial water bodies it is necessary to take into account the displacement of a riverbed in recreational areas hosting tourist routes.

The issues of deformation of river channels under natural conditions and conditions of anthropogenic load require detailed research. Therefore, great attention to the study of the state of river basins and individual rivers, the study of the impact of channel processes on the environment, is fixed in European and Ukrainian documents.

Due to the insufficient knowledge on channel processes, flooding of settlements occurs. Accidents at various structures and utility lines happen as the result of absence or lack of data on the morphodynamic characteristics of river channels, changes in the channel regime and their relationship with the hydrological characteristics of rivers. In Ukraine, the issue of a profound study of rivers, taking into account hydrological and morphological analysis and assessment of the intensity of channel transformation, has become acute recently.

216
The relevance of the problem of determining changes in river channels and monitoring them is confirmed by a number of state and administrative decrees and recommendations, as well as numerous research works on this topic. In 1995 the Water Code was adopted; in 2001 - the Land Code; various Resolutions of the Cabinet of Ministers of Ukraine concerning water protection activities were adopted in 1996 and 2009. In the Land Cadastre, the study of channel processes is associated with the determination of boundaries of water protection zones and the establishment of regulatory restrictions. In 2000, the EU Water Framework Directive was adopted, which defines the basic principles of water resources management and ways to achieve good water quality. One of the main principles, set out in this EU Directive, is an integrated basin-based model of water resources management, which provides for the joint actions of all states, located in the river basins. Directive 2007/60/EC of the European Parliament and of the Council of the European Union on the assessment and management of flood risks, presents an action plan for the assessment and management of flood risks aimed at reducing negative impacts on human health, the environment, cultural heritage and economic activity. The Expert Group is engaged in the development of the flood protection plan, which has the best practices and specific recommendations for the protection of the Danube River from floods. In Poland, IT System for the Country's Protection Against Extreme Hazards project (the ISOK project) has been developed. It is aimed at creating a system capable of improv the protection of the economy and society from extreme threats, in particular from floods.

Among other problematic issues, considerable attention to the study of channel processes is provided by the World Wide Fund for Nature (WWF), a branch 
of which operates in Ukraine. A special Water and Rivers Commission deals with the problem of degradation of rivers and channel processes. Such researches contribute to the prevention of natural hazards and their consequences, to reduction of material losses and, most importantly, to protection of human life.

There are two mutually exclusive processes associated with rivers. Since rivers are the water sources for settlements, water is taken from them for life and economic needs. Often, water is intaken not only ineffectively, but also irresponsibly without observing sizes of water protection zones, and documents regulating these sizes have not been revised or specified for decades. This promotes ruination of the floodplain, its housing development, erosion processes and, as a result, the siltation and degradation of rivers. This problem, which relates mainly to the steppe territories of Ukraine, but also occurs in other regions, is emphasized in P. Yatsyk's work (Yatsyk et al., 1991). Other hazardous phenomena, namely high flows and floods, are dangerous as they lead to huge material losses and even human casualties.

In the 21st century in the Carpathian and Pre-Carpathian regions there have been three significant destructive floods: in 2008, 2014 and 2020 (June 23-28). The flood in 2020 was especially powerful. The greatest losses were suffered by Ivano-Frankivsk and Chernivtsi regions, although "the big water" also caused a lot of damage in Lviv and Zakarpattia regions. Due to torrential rains, the Carpathian rivers, the Black and the White Cheremosh overflowed their banks, and in a couple of days - the same happened with the Dniester and Prut rivers. All rivers in the regions where devastating floods occur originate in the Carpathians. Witnesses to the 2020 flood witnesses recalled how the water flow rapidly increased, without encountering any resistance, sweeping away everything in its path, carrying huge stones from the mountains, trunks of trees torn with their roots, several non-residential buildings, heaps of waste were often dumped near rivers. The water rose so quickly that it was not possible to save any household property and cattle. In the village of Yasinya, Zakarpattia region, the water rose by 1 meter in one hour. The Prut rose by 5 meters, near Galych the Dniester reached an unprecedented level, i.e. 7 meters. This flood is considered the greatest in the past 60 years in Western Ukraine. According to the Ecological League experts (www.ecoleague.net), 14,000 houses, thousands of kilometers of roads were destroyed, 150 bridges and other infrastructure objects were ruined or significantly damaged. Some villages of the Carpathians remained encircled by the high water and completely cut off from the world due to large landslides that blocked roads and became threatening to houses. Crops, household goods and belongings were destroyed. To help the population and eliminate the consequences of the flood, 1,500 national guardsmen and rescuers were involved. According to preliminary estimates, the costs for overcoming the consequences of the disaster amount to UAH 4-5 billion.

It is obvious that the reason for the floods that have afflicted the Pre-Carpathian region, Bukovyna and Zakarpattia during the previous centuries, was torrential rains, that is, a natural factor, but in several publications (Kovalchuk, 2003, Parpan and Olijnyk, 2009), the reasons are associated with anthropogenic factors: the housing development of the floodplain, extraction of stone, gravel and sand from channels, but deforestation is considered the most important among them.

Knowledge on the patterns of development of channel processes allows for more rational use of rivers and their ecosystems, and ignoring them leads to negative consequences, in particular, to the destruction of hydraulic structures, erosion of banks, landslides, etc. Obeying the objective laws of channel formation, nevertheless, channels undergo constant changes caused by the human activity.

To effectively solve management problems, including those related to channel processes, it is necessary to use a complex approach, based on the utilization of satellite images of different spatial resolution for monitoring channel processes, images from UAVs, topographic and special maps with their follow-up processing using GIS technologies. It will allow one to take into account the main factors that significantly affect the said processes, namely deforestation of the river basin, extraction of building materials from channels, and housing development on land in the floodplain.

The task of our research study is to monitor the horizontal displacements of the Stryi River starting from the headwaters to the mouth where it flows into the Dniester River and analyse the impact of the most important natural and anthropogenic factors significantly influencing these displacements. The effect of geological and sedimentary structures, the peculiarities of geomorphology, changes in the riverine area due to the deforestation and extraction of building materials from the river channel and floodland are considered.

The results of monitoring the deformation processes occurring in the channel should be taken into account when solving problems related to river channel processes, namely the construction of hydraulic structures, the design of power transmission networks or gas pipelines across rivers, the determination of 
hazardous flooding zones, consequences of destruction after floods, the establishment of boundaries of water protection zones, the management of recreational activities, monitoring of border lands and the establishment of an interstate border along rivers.

The research study objective is to determine the hydrological changes in the Stryi River channel and the factors that cause these changes. In particular, we considered the influence of such natural factors as geomorphological and hydromorphological; geological, lithological and anthropogenic: deforestation on the slopes within the riverbed territories and the extraction of boulder-gravel materials from the riverbed and floodplain. It has been established that the first catalysts of channel changes are high water and flood phenomena. Common consequences of these natural phenomena are not only changes in the parameters of the channel, its bottom topography, such as meandering, but also huge material and social losses. Therefore, the issues of deformation of riverbeds under natural conditions and conditions of anthropogenic load require detailed research.

\section{Literature review}

Changes in morphological characteristics and riverbed displacements. The study of the stability of river channels is closely intertwined with studies of their horizontal reshaping, as well as the factors influencing them, their direction and intensity. These main reasons for studying channel processes are indicated in (Shuliarenko, 1998).

Due to the removal of a significant amount of sediment from the mountains and the flood regime of the Pre-Carpathian rivers, their channels are actively changing and deforming. The flow is influenced by the geological and geomorphological structure, which determines free or limited conditions for the development of channel displacements, which in turn determine the width of the valley bottom, the channel itself and the floodland. Actually, water runoff, geological, and geomorphological structure are the leading natural factors of channel processes.

The designed methodology based on the application of remote sensing data and geoinformation technologies allowed us to determine and analyze planned displacements of the Dniester and Tisza rivers (Burshtynska et al., 2016). The obtained results indicate the influence of geomorphological and geological factors on the channel displacement. The research data cover a period of 140 years. The maximum displacements for the Tisza are $930 \mathrm{~m}$, for the Dniester they are 620 $\mathrm{m}$. The Tisza basin is twice the size of the Dniester basin, which explains the greater water flow. In addi218 tion, the greater hydrological regime is influenced by the geomorphological factor, in particular the heights from which the tributaries of the Tisza flow down (1000 - $2020 \mathrm{~m}$ above sea level). The Dniester and its tributaries flow down from the altitude of 900-1200 m above sea level. Large floods are observed in the Tisza basin, since, in addition to summer floods, winter and spring floods are observed for the Tisza tributaries, especially typical for the Teresva, Borzhava and others. But the geological structures along which these two rivers flow are identical. For the Dniester, these are the Skybovi Carpathian Mountains and the UCF, while for the Tisza they include the Skybovi Carpathians and the Trans-Carpathian Deep, neither of which differ significantly. The methodology for monitoring channel displacements and the research results were presented at the ISPRS Congress in 2016.

In (Burshtynska, 2017), a methodology for monitoring the displacements of the Dniester River from the town of Galych to the town of Zalishchyky is considered and the specifics of the displacements for various sections of the plain and canyon parts are presented.

The research, empowered by new approaches and technologies for monitoring channel processes, is presented in (Burshtynska et al., 2019). It testifies to a significant difference between the values of horizontal displacements of the right-bank and left-bank tributaries of the Dniester river, located on different geological structures: the former are located within the UCF, the left-bank ones are located within the Volyn-Podilsk Upland. In the same research work, mathematical expressions for determining the stability of channels, proposed by various authors, have been analyzed.

Channel changes significantly affect natural and cultural landscapes as well as human economic activities. On the other hand, anthropogenic activities, in particular mining and construction works in the river valleys also cause changes in the river channels and significant environmental problems. Substantial displacements of the Stryi River channel, associated with the features of the lithological structure, as well as with hydrological and ecological disturbances of the channel and its floodland, are indicated in (Shevchuk and Burshtynska, 2011). The paper presents an analysis of the horizontal displacements of the Stryi River over a 140 -year period and indicates that they have reached $1,200 \mathrm{~m}$ in its mouth part.

The influence of the upper geological structures on the character of the Dniester River and its rightbank tributary in the piedmont part is considered by (Rudko and Petryshyn, 2014). Actually, the specific geological structure of the UCF with its thick deposits 
of gravel and sand has become not only a place for the extraction of this valuable raw material, but also a territory of significant environmental disturbances and losses. The authors note that boulder-gravelsandy rocks within Ukraine are distributed very unevenly. Their significant reserves are concentrated in the UCF. They were formed by Quaternary alluvial, deluvial, fluvioglacial and aeolian deposits. They occur as lenses and stratal deposits up to 20-25 m thick at a depth of 0-3.0 m.

Monitoring of the Stryi River estuary for the period of 1896-2006 was performed by means of a similar methodology using topographic maps and Google-images (Horishnyi, 2014). The author emphasizes that the riverbed displacement is associated with the lithological structure of the UCF. Interesting studies of changes in the Stryi riverbed, dependent on the extraction of raw materials for the production of building materials, are presented in (Volosetskyi and Shpyrnal, 2013).

Large-scale studies of riverbed deformations are carried out in different countries. Thus, in (Buffington et al., 2014), the influence of topography, geology, climate, vegetation, and land use on the spatial and temporal change of channel processes in the Pacific Northwest is indicated. The authors investigate the influence of channel types on physical models, which can be used to predict changes in channel morphology.

The relationship between the topography of the earth's surface and the hydraulic characteristics of a channel, in particular the influence of surface and underground water flows, as well as studies of the morphology and structure of the Amazon River channel, are presented in (Beighley et al., 2009).

Scientists from the Great Britain (Hooke, 2006) investigated the intertwining and tortuosity of singlethread and multi-thread river channels with the determination of meandering and interlacing coefficients. It is noted that multi-threaded rivers are more meandered than single-threaded ones.

Studies of the problems of channel processes in Western Australian rivers are presented in (Janicke, 2000). The influence of anthropogenic factors on the transportation of sediment and siltation is noted. Attention is drawn to the solution of the problem of degradation of rivers and channel processes, which is dealt with by a special Water and Rivers Commission.

In (Guneralp et al., 2011) the migration of the Brazos River in Texas over the period of 1910-2010 has been analyzed. Topographic maps and satellite images of different time periods were used. Not only the migration of the channel, but also the meanders, the slope and the shape of the channel of this river have been studied. Channel migration zones, which combine historical channel displacements and forecast future displacements, have been identified presenting an analytical tool for forecasting areas that may be at risk of catastrophic floods.

In (Legg and Olson, 2014) the objects of study are the rivers of Western Washington, in particular, the riverbeds' migration is investigated. It is indicated that channels migrate within the floodplains due to the processes of channel expansion, changes in bends and their frequency.

Stratigraphic, geomorphological, and paleoecological data were collected from high-altitude water intake areas in the Great Basin of Central Nevada to assess the relationship between the Late Holocene climate change, land-forming processes, forest cover, and modern channel dynamics (Miller et al., 2001). They indicate that the transition to drier, warmer climates 1300-2500 years ago led to a complex set of geomorphological reactions. The initial reaction was massive erosion of mountain slopes and, simultaneous gravitation of lateral valley alluvial deposits. It was replaced by sediment stabilization, as finegrained sediments formed from rocks, and, in particular, changes in sedimentary processes and runoff occurred. It has been proven that the current dynamics of channels and associated bank ecosystems significantly affect the shape of forests.

New Orleans professor Stephen A. Nelson explains the formation of meanders as follows: due to the rate of change in the structure of the flow, especially in rivers with easily eroded soils, straight sections become tortuous. At the outer part of the meanders, at the bends, where the flow rate is the highest, the development of soil erosion occurs. Silting occurs along the interior part, where the velocity is low (Nelson, 2012).

Deforestation impact. Let us consider some works related to another factor that has a significant impact on the hydrological regime of rivers, i.e. the deforestation in the river basin.

The monograph (Kovalchuk, 2003) comprehensively considers natural factors of channel processes, in particular, the state of the river flow in the Dniester basin and the amount of precipitation in the region over the second half of the 20th century. The monograph highlights the insufficient amount of afforestation of water intake areas $(40.2 \%$ in the Ukrainian Carpathians and $25 \%$ in the Pre-Carpathians). The study also notes the state of forests, including excessive forest felling, changes in the age and species composition of forests, anthropogenic reduction of its upper boundary by $200-300 \mathrm{~m}$, as well as the fact that the percentage of afforestation in the Carpathians is 
steadily decreasing.

Environmentalists of the state agency of Ukraine have long been concerned about unauthorized deforestation. Studies (Kabal, 2016) indicate a great role of forests in maintaining water balance. The optimal forest cover for elementary water intake areas should be $65-70 \%$. Trees begin to accumulate water after reaching 40 years of age.

In (Parpan and Olijnyk, 2009) the formation of floods, the structure of forests and their water regulating role in the Ukrainian Carpathians has been analyzed. There are also proposals for enhancing the protective properties of forests. As initial data, the statistical data on the calculation of afforestation in the region, as well as hydrological and experimental studies over a 50-year period were used. Scientists point out that the forest in the Carpathians reduces the flow of water on the slopes by about 4-5 times, the trunks and crowns of trees restrain water flows by $20-30 \%$. The forest prevents landslides, while in dry weather it contributes to the feeding of rivers with groundwater.

In (Bayrak, 2011) the issues of deforestation in the Pidbuzh river basin, as well as changes in its hydrological regime have been considered.

The paper (Burshtynska et al., 2014) is devoted to the problems of forest felling in the Carpathian region. Satellite images with high spatial resolution were used for the study. The study has established that satellite images can be used to detect not only areas, but also the time of felling. In (Kokhan et al., 2020), a new approach to the use of vegetation indices for vegetation identification has been proposed.

The state of forests in Uganda is discussed in (Josephat, 2018). Uganda is noted to have suffered the adverse effects of climate change, especially during the last decade, as evidenced by numerous periods of erratic rainfall, prolonged droughts, floods, repeated mudflows, thunderstorms, increased pests and diseases, hunger and declining agricultural productivity. The population growth and migration have increased the demand for agricultural land and firewood, and rural poverty limits the ability to invest in sustainable land management practices.

The Yangtze River flood in 1998 (Xin Zong You, 2012) set the limit for the Chinese government to take measures to protect the environment for sustainable development. The Chinese government strictly banned deforestation in the wake of the disaster, prompting mixed criticism from the international community. However, based on the literature reviewed, it was concluded that forest and flood are closely related to each other, and deforestation does have a huge impact on the intensity of floods or their frequency.
For centuries, forests have been believed to provide flood protection. However, such claims created controversy, and there was no large-scale quantitative evidence of a possible role for forests in flood protection. Using data collected during 1990-2000 in 56 developing countries, the authors (Bradshaw et al, 2007) prove, that with a decrease in the area of natural forests by $10 \%$, the average model forecasting of the frequency of floods increases within $4 \%-28 \%$ among the simulated countries, and also led to an increase in the total duration of floods by $4-8 \%$.

The article (Ali, 2014) focuses on the study of the role of deforestation, its impact on climate change and its consequences in Pakistan. Forests protect biodiversity, soil and regulate the hydrological cycle, air temperature, help to cope with the effects of climate change. With the population growth and the trend towards urbanization, the rate of deforestation has increased, disrupting natural atmospheric and climate patterns and exacerbating the devastating impact of natural disasters, including catastrophic floods.

Carbon emissions and the risk of deforestation are high on the list of globally important externalities (Buys, 2007). For example, a strong global commitment to the Framework Convention on Climate Change, which calls for the stabilization of greenhouse gases' release in the atmosphere, would mean conditions for the conservation of forests. The hydrological effects of deforestation are extremely sensitive to local conditions. In the past, politics was influenced by hydrological myths, including that forests produce water. Reliance on these myths has backfired forest restoration and may have undermined efforts to protect forests.

Current knowledge shows that the greatest benefits from watershed management occur within small watersheds, in small steep basins from which cities intake water, or along river boundaries. Fine-tuning the behaviour of a watershed requires attention not only to the presence or absence of trees, but also to their placement, agricultural activities, and especially the placement and maintenance of roads. On the other hand, the conservation of forests, motivated primarily by biodiversity, can stabilize the hydrological regime in the basins of large rivers. However, the scientific understanding of hydrological processes is incomplete. In some cases, large-scale deforestation can affect the regional climate. There is also discussion of the extent to which deforestation can reduce runoff during the dry season. Detailed scientific and economic research is needed to identify situations in which deforestation poses these risks.

The article (Li-An et al., 2018) indicates that the global increase in the frequency and extent of floods 
is caused by anthropogenic activity. From 1980 to 2009 , floods killed more than 500,000 people and affected more than 2.8 billion people worldwide. Through urbanization, deforestation and large-scale agricultural activities landscape alteration contributes to flooding urban and rural areas. Industrialization in developing countries increases carbon emissions by activating an aerosol-induced mechanism. As a result, a catastrophic flood occurred in Sichuan in 2013. In addition, rainfall in urban areas has increased due to the urban heat island effect.

\section{Materials and methods}

The Stryi River is the largest right tributary of the Dniester, which originates at an altitude of 1,120 meters. The length of the river is $232 \mathrm{~km}$. In the highland part, the river flows along a narrow valley, the average channel width is $30-50 \mathrm{~m}$. In the hilly part, the width of all spits can reach up to $120 \mathrm{~m}$. In the lowland part, the width does not exceed $80 \mathrm{~m}$.

Materials of different time periods used for research require an assessment of the accuracy of their transformation. These researches were carried out by the method of coordinate transformation using power polynomials by means of ArcGIS 10.1 software product. Since the topographic maps used were created in different time periods and in different cartographic projections, and satellite images are stored in the UTM projection (Table 1), it is necessary to normalize all available materials to the universal topographic Mercator UTM projection. where: $x^{i}, y^{j}$ are coordinates of the first projection taking into account the average value;

$X, Y$ are coordinates of the second projection;

$X_{0}, Y_{0}$ are coordinates of the average value of the second projection;

$a_{i j}, b_{i, j}$ are conversion function coefficients.

To convert the $n$-th power it is necessary to have at least $p_{n}$ common points:

$$
p_{n}=p_{1}+\sum_{i=2}^{n}(i+1)
$$

where: $p_{l}$ is the number of common points for the transformation of the first degree.

For the reference common points were used, which are identified on topographic maps and images: bridges, crossing points on railway tracks, places of worship, etc. The transformation is carried out by a 2nd degree polynomial using 10 common points. For comparison, Table 2 shows the alignment accuracy using 1 st and 2 nd degree polynomials.

\section{The research results}

Geological and sedimentological structures The Stryi River crosses the following geological structures of western Ukraine - thrust-and fold elements of the Ukrainian Carpathians, the UCF, (the inner and outer zones). The question of how geological features have influenced and still influence the nature of the river arises. Another question is how the river itself influences the formation of some geological

Table 1. The main materials for the study of horizontal displacements of the Stryi River channel

\begin{tabular}{|c|c|c|c|c|c|}
\hline No & Input materials & $\begin{array}{c}\text { Year of publi- } \\
\text { cation / survey }\end{array}$ & Ellipsoid & Projection type & Coordinate system \\
\hline 1. & Topographic map (Austria-Hungary) & 1874 & $\begin{array}{c}\text { Austrian ellipsoid } \\
\text { of } 1810\end{array}$ & Zoldner - Cassini & $\begin{array}{c}\text { Halychyna coordinate } \\
\text { system }\end{array}$ \\
\hline 2. & Topographic map (Poland) & 1933 & $\begin{array}{c}\text { Austrian ellipsoid } \\
\text { of } 1810\end{array}$ & Zoldner - Cassini & $\begin{array}{c}\text { Halychyna coordinate } \\
\text { system }\end{array}$ \\
\hline 3. & Topographic map (USSR) & 1990 & Krasovsky & Gauss - Krueger & SK-42 \\
\hline 4. & Sentinel 2 satellite images & $2019 / 2020$ & WGS-84 & UTM & WGS-84 \\
\hline
\end{tabular}

A power polynomial is used to transform one map projection into another. The formula for transforming one cartographic projection into another using power polynomials is:

$$
\begin{aligned}
& X=X_{0}+\sum_{i=0}^{n} \sum_{j=0}^{n} a_{j} x^{i} y^{j} \\
& Y=Y_{0}+\sum_{i=0}^{n} \sum_{j=0}^{n} b_{j} x^{i} y^{j}
\end{aligned}
$$

Table 2. The main materials for the study of horizontal displacements of the Stryi River

\begin{tabular}{|c|c|c|c|}
\hline \multirow{2}{*}{ River } & Map & $\begin{array}{c}\text { Polynomial of } \\
\text { the 2nd degree } \\
(\mathbf{m})\end{array}$ & $\begin{array}{c}\text { Polynomial of } \\
\text { the 1st } \\
\text { degree (m) }\end{array}$ \\
\hline \multirow{2}{*}{$\begin{array}{c}\text { The } \\
\text { Stryi }\end{array}$} & $\begin{array}{c}\text { Austrian } \\
\text { period }\end{array}$ & 20 & 34 \\
\cline { 2 - 4 } & Soviet period & 15 & 20 \\
\hline
\end{tabular}


formations, such as alluvial deposits. A very important factor that should be taken into account is the influence of man on the processes taking place in and around the river. The Stryi River has a length of $232 \mathrm{~km}$, the area of the basin is $3,060 \mathrm{~km}^{2}$ (Fig. 1).

Geomorphologically it intersects the Carpathians and Pre-Carpathians. In the Carpathians, the Stryi River has a mountainous character with a narrow valley, while in the Pre-Carpathians it is partly a plains river. nappes is composed of layers of sandstones, siltstones and argillites, which form the so-called flysch. The thickness of the flysch complex in the thrusted state is $12 \mathrm{~km}$.

The Cretaceous deposits in the study region were formed in two different tectonic and paleogeographic conditions, i.e. platform and geosynclinal ones (Havrylyshyn et al., 1991). Mostly, the direction of the riverbed of the Stryi River is caused by tectonic factors, namely regional faults transverse to the

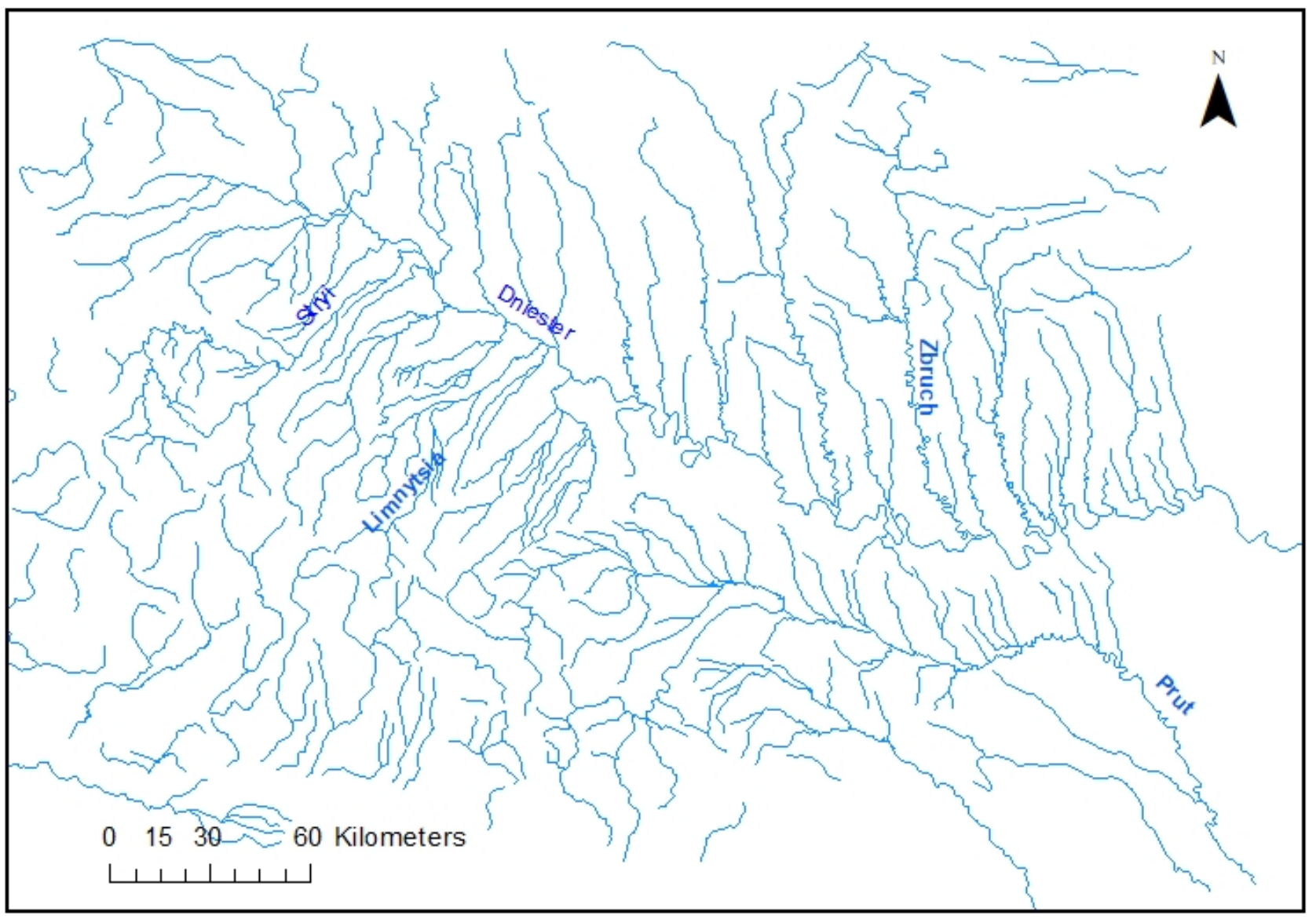

Fig.1. The location of the Stryi River in the Dniester River basin

The Stryi River crosses two high order structures, i.e. the thrust and folded-belt of the Ukrainian Carpathians and the UCF which superimposes the platform (Fig. 2).

A number of structures - nappes - have been identified in the thrust and folded-belt (Bubniak I., Bubniak A., 1997). It runs through two nappes of the Ukrainian Carpathians - Krosno and Skyba. The other two nappes through which the Stryi Rriver flows - Boryslav-Pokuttia and Sambir ones - belong to the UCF (Nakapelyukh et al., 2018). Adjacent to these structures from the east is the Bilche-Volytska zone (Outer) of the UCF, which is an autochthonous tectonic unit. All these nappes (except Sambir) are composed of formations ranging in age from the Cretaceous to the Neogene. The bulk mass of the 222
Carpathians. Part of the Stryi tributaries is also controlled by faults of smaller orders and fractured zones, which have a fairly regular location (Hintov et al., 2011). Although there are some exceptions, for example, the meander of the Stryi River near the village of Rybnyk may be due to the composition and mechanical properties of rocks. The situation is significantly different in the Bilche-Volytska zone of the UCF. The foredeep is filled with upper molasses and Quaternary sediments, which differ in lithological composition and mechanical properties from flysch. Here, in our opinion, the main factors influencing the deformation of the channel are lithological ones.

Geomorphological factors. The geological and sedimentological structures along which the Stryi River flows, determine the diverse relief of the territo- 


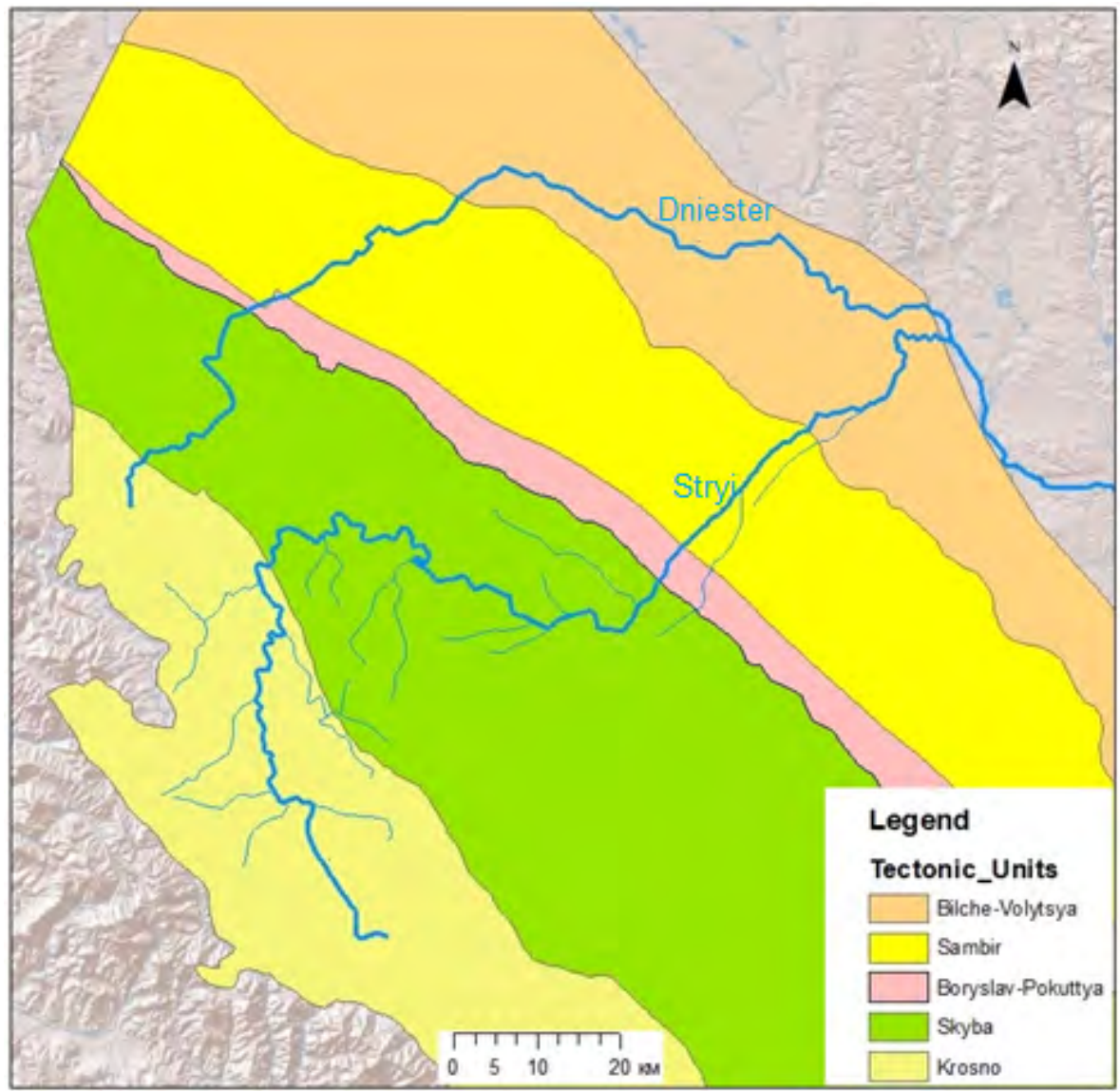

Fig.2. The main tectonic structures of the Stryi River basin

ry. In the upper part there is a mountainous relief with narrow valleys. The lower part of the course of the Stryi River is conditionally divided into piedmont and plain. This division is due to the different nature of the riverbed in these areas. In the piedmont part, the river is characterized by a significant number ofbraids and the absence of meandering. In its lowland flat part, the river flows practically as one channel with significant meandering and the presence of oxbow lakes. A fragment of a digital elevation model with an overlaid digitized channel of the Stryi River is shown in Fig. 3.

Study of the Stryi River displacements. It is no wonder that this river was chosen for monitoring since the Dniester and part of its right-bank tributaries, including the Stryi, are located in the UCF Within this foredeep, the Stryi Deep is distinguished, which significantly influenced the nature of the riverbed, its floodplain and valley (Table 3 ). In some places the Stryi has a very winding channel. In particular, it makes a large meander near the village of Rybnyk, which is not typical for the mountainous part.

Monitoring was carried out for over a 140-year period. The Stryi River was conditionally divided into mountain, piedmount and flat parts. To monitor the Stryi River channel meandering, the following were used: topographic maps scaled 1: 75000 (1874) and 1: 100000 (1933 and 1990); satellite images obtained from the Sentinel-2 satellite (2019 and 2020), for the mountainous part a high-resolution image from the Bing service was also used; 1: 200000 scaled maps of the Quaternary sediments (1970) and a soil map (1967). The methodology for performing the study is presented in (Burshtynska et al., 2017, Burshtynska et al., 2018).

Table 3. The main characteristics of the Stryi River

\begin{tabular}{|c|c|c|c|}
\hline $\begin{array}{c}\text { Characteris- } \\
\text { tics of the } \\
\text { river }\end{array}$ & $\begin{array}{c}\text { The upper } \\
\text { (moun- } \\
\text { tainous) } \\
\text { part }\end{array}$ & $\begin{array}{c}\text { Middle } \\
\text { (pied- } \\
\text { mont) } \\
\text { part }\end{array}$ & $\begin{array}{c}\text { The lower } \\
\text { (plain) part }\end{array}$ \\
\hline
\end{tabular}

The main hydrological and morphometric characteristics

\begin{tabular}{|l|c|c|c|}
\hline Width, $\mathrm{m}$ & $10-90$ & $30-120$ & $30-80$ \\
\hline Depth, $\mathrm{m}$ & $0.5-1.5$ & $1.0-2.5$ & $3.5-4.0$ \\
\hline Speed, $\mathrm{m} / \mathrm{s}$ & 0.9 & 0.4 & 0.2 \\
\hline Slope $\mathrm{m} / \mathrm{km}$ & 5 & 1.7 & $0, .8$ \\
\hline
\end{tabular}

Meteorological and hydrological characteristics

\begin{tabular}{|c|c|c|c|}
\hline $\begin{array}{c}\text { Precipitation, } \\
\mathrm{mm}\end{array}$ & 1,200 & 900 & 800 \\
\hline $\begin{array}{c}\text { Average an- } \\
\text { nual runoff, } \\
\mathrm{m}^{3} / \mathrm{s}\end{array}$ & 20 & 35 & 50 \\
\hline
\end{tabular}




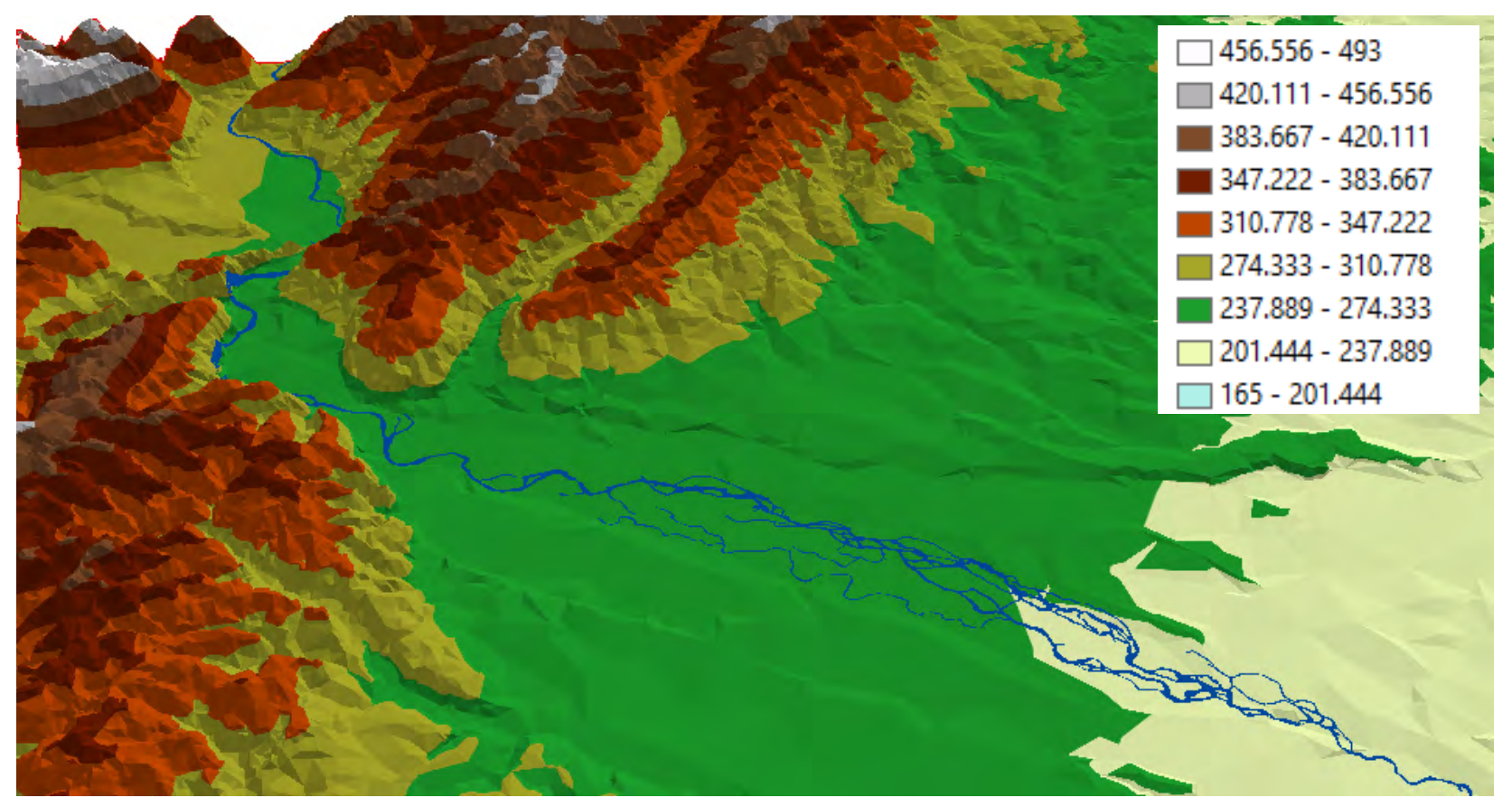

Fig. 3. Fragment of the TIN model with the overlaid Stryi river channel during its transition from the mountainous to the piedmont part

Mountainous part. The mountainous part of the river is characterized by the presence of one channel. The difference in height from the source to the exit of the river to the piedmont territory is about $750 \mathrm{~m}$ within a $150 \mathrm{~km}$ long section, that is, on average $5 \mathrm{~m} /$ $\mathrm{km}$. A fragment of a section of the Stryi riverbed in the mountainous part is shown in Fig. 4. Since the valley of the river flow in the mountainous part is predominantly narrow, the values of channel displacements during the study period are relatively small. The results of measurements of channel displacements in areas with maximum deviations when approaching the piedmont part of the channel are presented in Table 4. The maximum displacement recorded in this area is $200 \mathrm{~m}$.

Enlarged fragments of the channel with details of the maximum changes are shown in Fig. 4. In the mountainous part, only 9 points were selected to determine the displacements (in the places of the greatest deviations), since in this part the channels practically overlap. The maximum displacement value obtained for the years of 1874-2019 is $200 \mathrm{~m}$, that is, the displacement is relatively insignificant. In the mountainous part, the displacements are insignificant and do not exceed the accuracy of the representation the topographic map.

Piedmont part. The length of the piedmont part of the Stryi River (from the urban settlement of Verkhne Syniovydne, Skole district, Lviv region to the urban settlement of Gnizdychiv, Zhydachiv district, Lviv region) is about $50 \mathrm{~km}$. The drop in this section is 85 $\mathrm{m}$, that is, $1.7 \mathrm{~m} / \mathrm{km}$. This part is characterized by a
Table 4. Maximum displacements of the Stryi River channel in the mountainous part

\begin{tabular}{|c|c|}
\hline $\begin{array}{c}\text { Measurement point } \\
\text { number }\end{array}$ & Maximum displacement \\
\hline 1 & 130 \\
\hline 2 & 120 \\
\hline 3 & 120 \\
\hline 4 & 170 \\
\hline 5 & 160 \\
\hline 6 & 150 \\
\hline 7 & 200 \\
\hline 8 & 130 \\
\hline 9 & 140 \\
\hline
\end{tabular}

significant multi-braided structure of the river channel (Fig. 5). Therefore, for this section, the number of spits and the measured width of the distance between the outermost river threads are supplied (Table 5). In 1874 , the maximum spit width was up to $1.5 \mathrm{~km}$, the river was divided into 3-6 spits.

In more than 100 years (1990), the width between the outermost river spits decreased to 500 $\mathrm{m}$. In general, a decrease in the channel width is recorded in all sections of the river, which indicates a decrease in its water content. Within the piedmont part, the displacements are the differences between the width of the river spits. It should be noted that in this section the channel shifts in the north-western direction, which poses a risk that the international highway might be eroded.

Plain part. The most varied part of the river in 


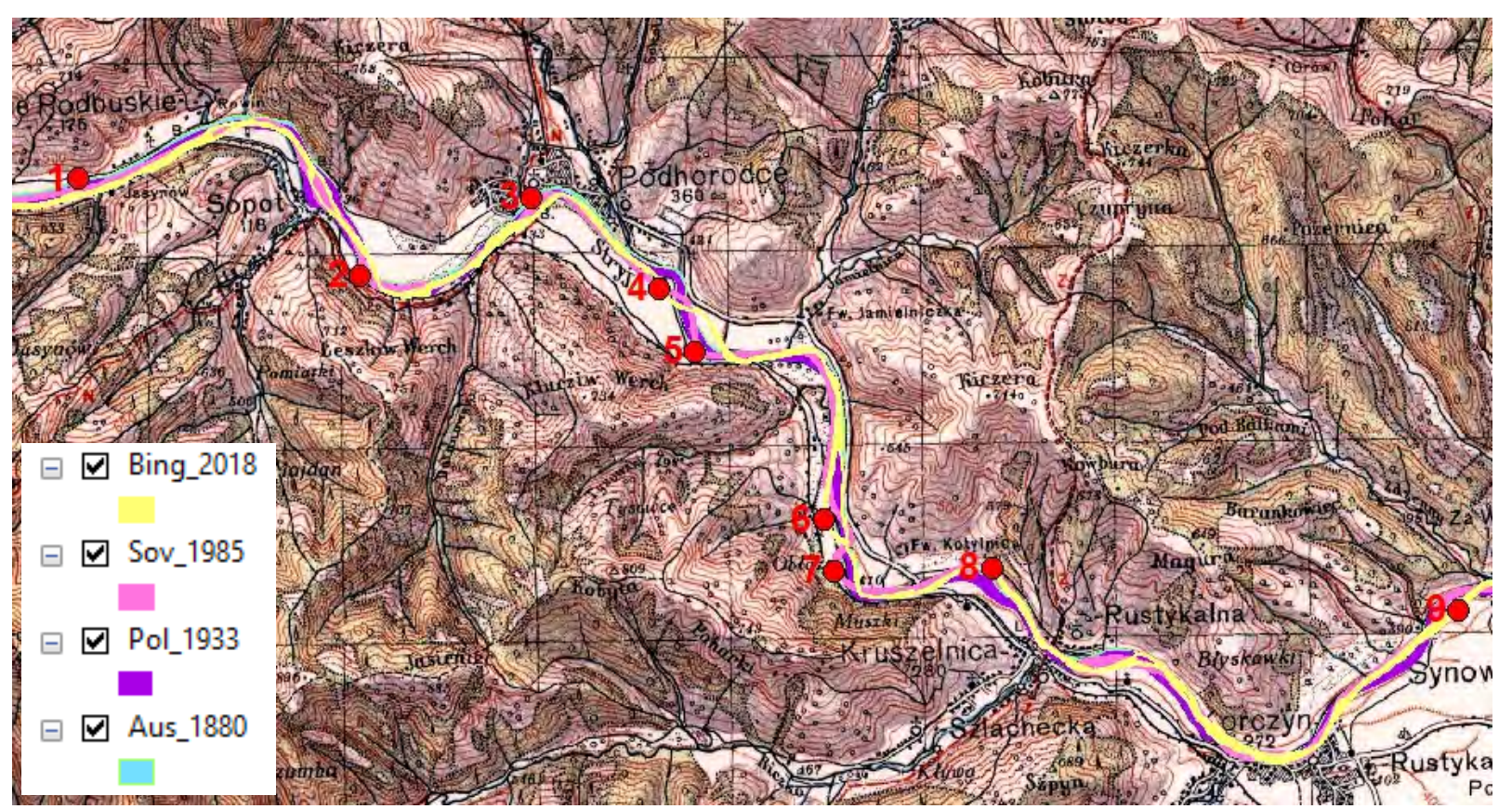

Fig.4. Fragment of digitized channels of the mountain part of the Stryi River overlaid on the topographic map of 1933 and places of displacement measurement

terms of changes and water regime is the channel located in the lowland part of the area up to its entering the Dniester River (Fig. 6). The length of the plain part of a large number of meanders and abandoned oxbow lakes, in some areas the terrain is swampy. The Stryi River makes the most interesting meanders near the

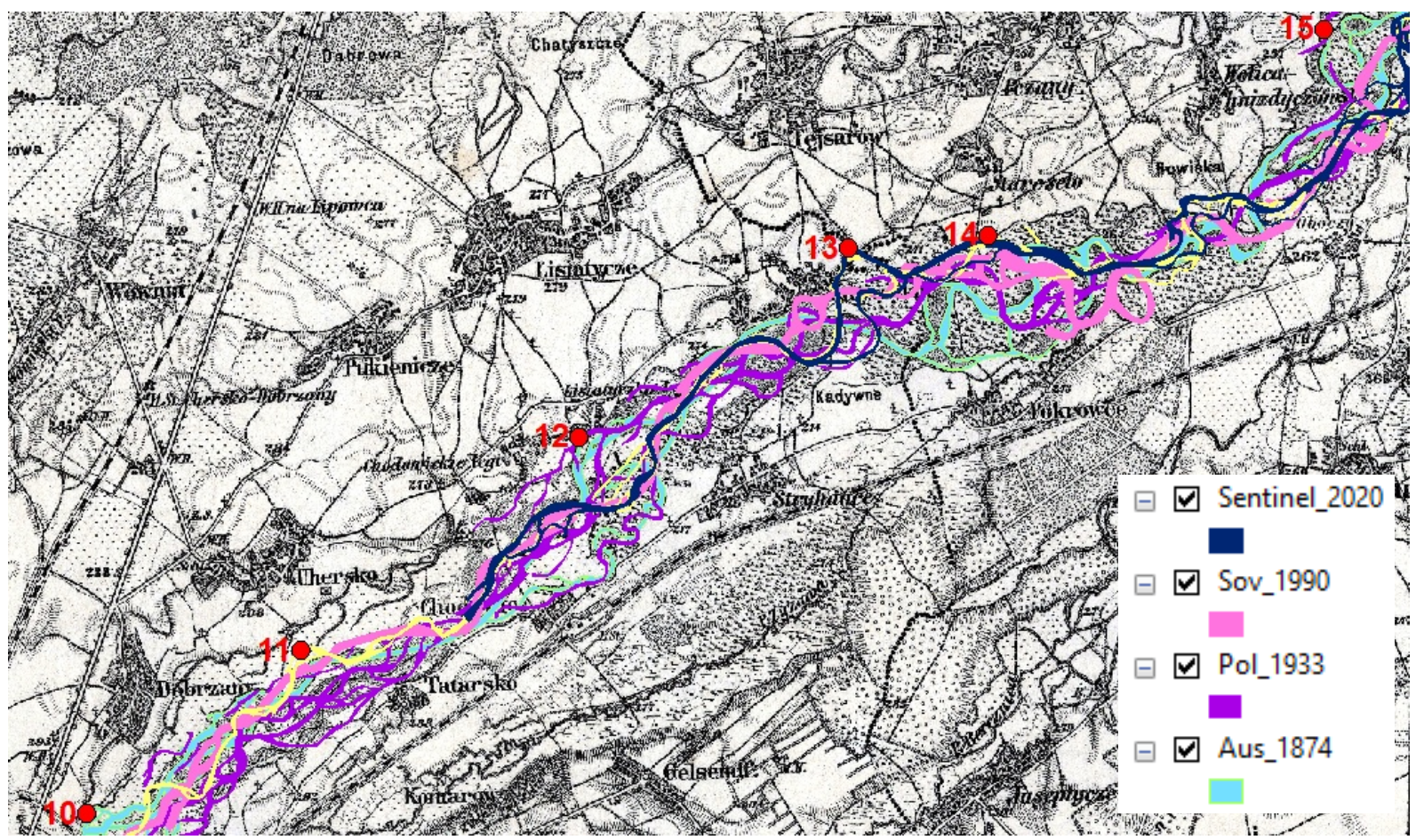

Fig.5. Fragment of digitized channel images of the piedmont part of the Stryi River overlaid on the topographic map of 1933 and sites of measuring the number of river channel braids

the Stryi River (from the village of Gnizdychiv, Zhydachiv district up to the inflow into the Dniester River near Zhydachiv, Lviv region) is $18 \mathrm{~km}$. The elevation difference in this section is $15 \mathrm{~m}$, that is, $0.8 \mathrm{~m} / \mathrm{km}$. In this part, the Stryi has a very winding channel with town of Zhydachiv, where it flows in several different directions for several kilometers. This part of the riverbed is mostly dependent on the geomorphological structure, which is characteristic of the UCF. The river, crossing sections of rocks of different hardness, 
forms valleys of various types, ranging from narrow, almost terraceless, to wide ones at the intersection with soft rocks. It is known, that deposits of various geological periods are included in the structure of the UCF. The UCF Quaternary sediments are represented by four types: old, middle, new and modern. The new type is associated with a continuous cover of loesslike loams. The modern includes sandy-pebble-clayey sediments of floodplains of river valleys, fan cones, swamps, alluvial-deluvial formations (Horishnyi, 2014).

used satellite images from the Landsat-7 (2000) and Sentinel-2 (2020) satellite systems. The imaging equipment of Landsat-7 satellite operates per the optoelectronic principle of scanning in eight spectral channels: panchromatic with a spatial resolution of $15 \mathrm{~m}$, six multispectral channels of visible, near and mid-infrared ranges with a resolution of $30 \mathrm{~m}$, and far infrared ranges with a resolution of $60 \mathrm{~m}$. Upon images synthesizing we applied a pan-sharpening method allowing receiving images with spatial resolution of $15 \mathrm{~m}$.

Table 5. The number of braids and the measured width of the distance between the outermost river spits

\begin{tabular}{|c|c|c|c|c|c|c|c|c|}
\hline \multirow{2}{*}{$\begin{array}{c}\text { Nos. } \\
\text { of } \\
\text { points }\end{array}$} & $\begin{array}{c}\text { The width of } \\
\text { the river spits } \\
\text { (m) }\end{array}$ & $\begin{array}{c}\text { Number of } \\
\text { the river } \\
\text { spits }\end{array}$ & $\begin{array}{c}\text { The width of } \\
\text { the river spits } \\
(\mathbf{m})\end{array}$ & $\begin{array}{c}\text { Number } \\
\text { of the } \\
\text { river } \\
\text { spits }\end{array}$ & $\begin{array}{c}\text { The width of } \\
\text { the river spits } \\
\text { (m) }\end{array}$ & $\begin{array}{c}\text { Number } \\
\text { of the } \\
\text { river } \\
\text { spits }\end{array}$ & $\begin{array}{c}\text { The width of } \\
\text { the river spits } \\
\text { (m) }\end{array}$ & $\begin{array}{c}\text { Number } \\
\text { of the } \\
\text { river spits }\end{array}$ \\
\hline $\mathbf{1 0}$ & 80 & 1 & 700 & 2 & 100 & 1 & 350 & 2 \\
\hline $\mathbf{1 1}$ & 490 & 2 & 650 & 2 & 420 & 2 & 140 & 2 \\
\hline $\mathbf{1 2}$ & 1,610 & 5 & 1,320 & 4 & 560 & 3 & 100 & 1 \\
\hline $\mathbf{1 3}$ & 1,550 & 5 & 1,720 & 3 & 520 & 2 & 160 & 2 \\
\hline $\mathbf{1 4}$ & 1,370 & 5 & 1,500 & 6 & 470 & 3 & 240 & 2 \\
\hline $\mathbf{1 5}$ & 1,190 & 6 & 1,250 & 6 & 750 & 3 & 670 & 2 \\
\hline $\mathbf{1 6}$ & 1,140 & 6 & 230 & 2 & 140 & 1 & 40 & 1 \\
\hline $\mathbf{1 7}$ & 100 & 1 & 730 & 6 & 120 & 1 & 150 & 2 \\
\hline $\mathbf{1 8}$ & 1,270 & 5 & 1,390 & 4 & 100 & 1 & 410 & 4 \\
\hline $\mathbf{1 9}$ & 250 & 2 & 880 & 3 & 90 & 1 & 560 & 2 \\
\hline $\mathbf{2 0}$ & 1,100 & 3 & 300 & 2 & 470 & 2 & 370 & 3 \\
\hline
\end{tabular}

One of threatening processes is the intensive extraction of gravel and sand from riverbeds, the development of deposits of boulder-gravel-sandy rocks on the Dniester, Stryi, Svicha and Opir rivers within the territory of Lviv region, which negatively affects the ecological state of the environment. Deposits of boulder-gravel-sandy rocks within Ukraine are distributed very unevenly.

Table 6 shows data on riverbed displacements. Table 7 shows the number of oxbow lakes and alluvial islands; the total area of oxbow lakes is calculated for the lowland part of the Stryi River near the town of Zhydachiv.

The reduced area of oxbow lakes in 1990 can be explained by the fact that only large oxbow lakes are indicated on the map, as well as those that contrasted significantly in-situ.

Deforestation and gravel removal from the riverbed. Recently, deforestation has increased manyfold, especially in the Carpathian region. It is know that in the absence of an active root system rainwater drains into the valley much faster and often causes floods. To determine the areas of forest felling we
Table 6. Riverbed displacements of the Stryi River plain part

\begin{tabular}{|c|c|c|}
\hline \multirow{2}{*}{$\begin{array}{c}\text { Nos. of } \\
\text { points }\end{array}$} & \multicolumn{2}{|c|}{ Riverbed displacements, $(\mathbf{m})$} \\
\cline { 2 - 3 } & $\mathbf{1 8 7 4 - 1 9 9 0}$ & $\mathbf{1 9 9 0 - 2 0 1 9}$ \\
\hline $\mathbf{2 1}$ & 600 & 500 \\
\hline $\mathbf{2 2}$ & 1,350 & 140 \\
\hline $\mathbf{2 3}$ & 900 & 80 \\
\hline $\mathbf{2 4}$ & 780 & 130 \\
\hline $\mathbf{2 5}$ & 330 & 260 \\
\hline $\mathbf{2 6}$ & 630 & 170 \\
\hline
\end{tabular}

Table 7. The number of oxbow lakes and alluvial islands within the Stryi River plain part

\begin{tabular}{|c|c|c|c|}
\hline Years & $\begin{array}{c}\text { Number of } \\
\text { oxbow lakes }\end{array}$ & $\begin{array}{c}\text { Oxbow lakes } \\
\text { total area, ha }\end{array}$ & $\begin{array}{c}\text { Number of al- } \\
\text { luvial islands }\end{array}$ \\
\hline 1874 & 20 & 129 & 12 \\
\hline 1933 & 20 & 95 & 6 \\
\hline 1990 & 20 & 142 & 2 \\
\hline 2019 & 12 & 104 & 2 \\
\hline
\end{tabular}

In order to obtain a digital terrain model, the Sentinel-2 satellite consists of two identical satellites Sentinel-2A and Sentinel-2B. The satellites are 


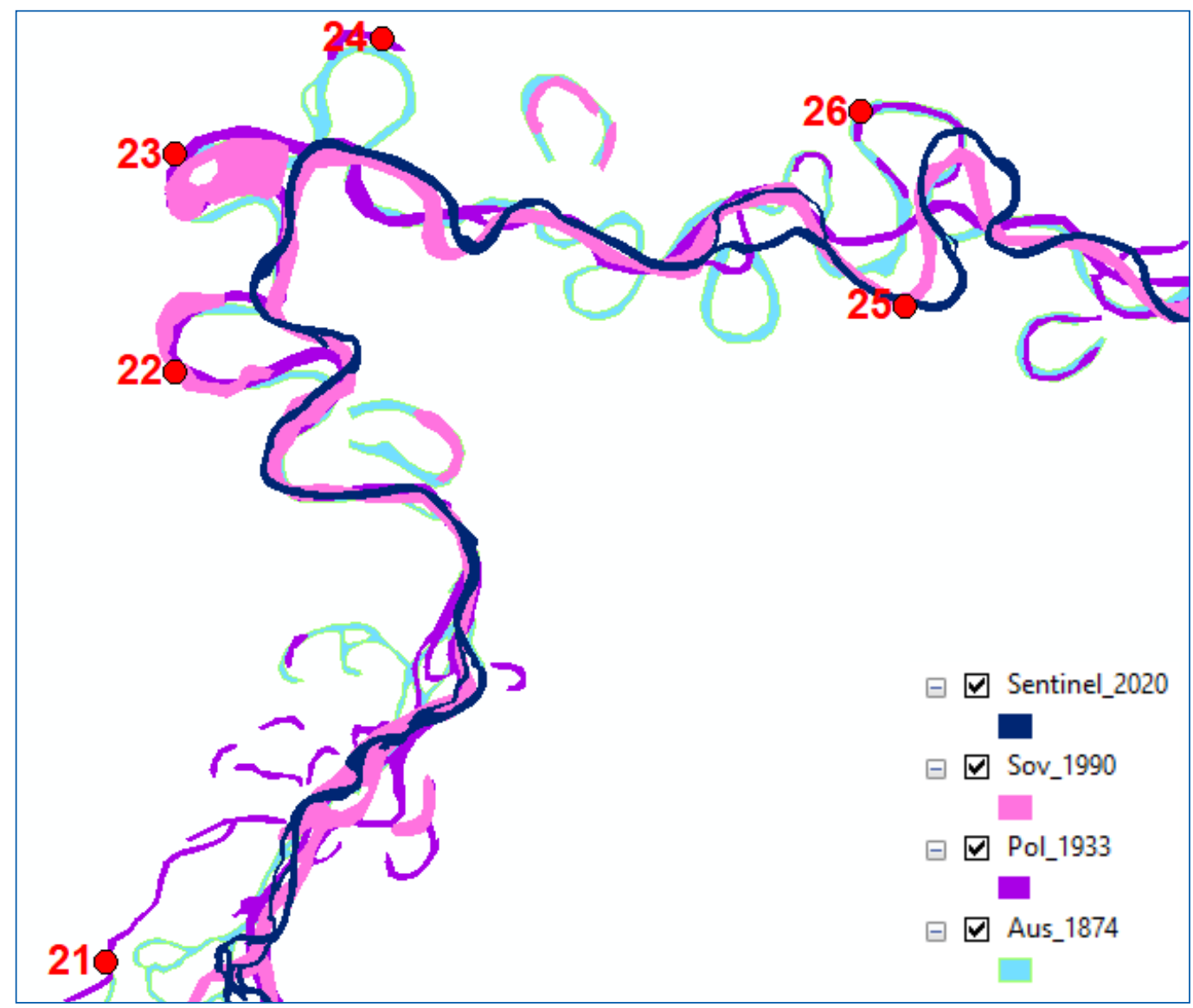

Fig.6. Fragment of digitized channel images of the plain part of the Stryi River and places of displacement measurement

equipped with optical-electronic tools, which operate in 13 multispectral ranges: visible, near and middle

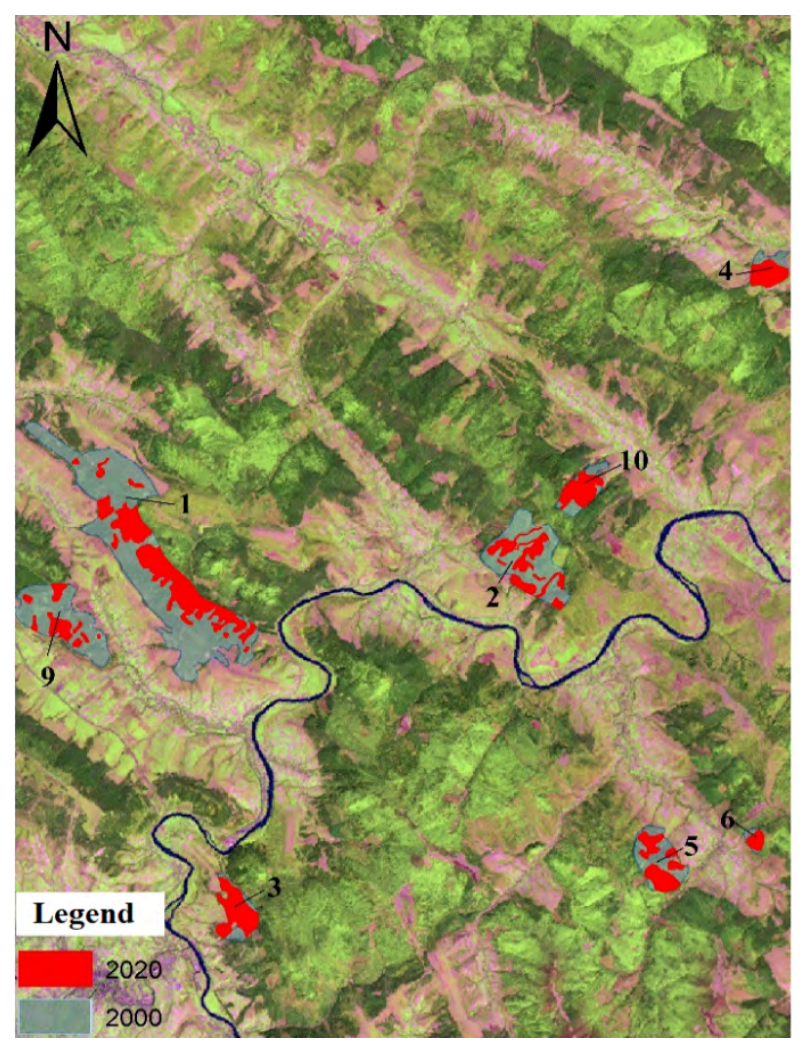

Fig. 7. Location of the study plots with deforestation traits along the Stryi River infrared ranges, the resolution of the equipment is 10 $\mathrm{m}, 20 \mathrm{~m}, 60 \mathrm{~m}$, and respectively.

Figure 7 shows post-processed and transformed images specifying the studied plots in the Turka forestry located within the Stryi River basin. On these plots, the areas of forest felling have been determined. The 2020 image shows fellings, which are distinguished by a clear geometric structure and a light tone (Fig. 8).

Table 8 shows the results of measurements of changes in the forest areas over a 20 -year period. The measurements were carried out at ten test sites by digitizing satellite images shot by Landsat-7 (2000) and Sentinel-2 (2020). Thus, it has been established that over a 20 -year period, the area of deforestation in these areas is about 540 hectares.

In Internet publications (https://varta1.com. ua/, https://stryi.in.ua/) there are reports that in the summer months, tons of gravel (up to 150 cars) are illegally extracted from the Stryi River every day. Such extraction could change the course of the river, leading to an environmental disaster. In support of these words, we present an image of the Stryi riverbed from the Google Earth service taken at the place of significant gravel extraction (Fig. 9) in 2009 and 2017.

The 2009 image shows how clearly visible the 
Table 8. Changes in forest cover areas for the period of 20002020 in the Stryi River basin

\begin{tabular}{|c|c|c|}
\hline $\begin{array}{c}\text { Plot } \\
\text { number }\end{array}$ & $\begin{array}{c}\text { Forest cover area in } \\
\text { 2000, ha }\end{array}$ & $\begin{array}{c}\text { Areas of deforestation } \\
\text { in 2020, ha }\end{array}$ \\
\hline $\mathbf{1}$ & 487.0 & 134.0 \\
\hline $\mathbf{2}$ & 159.6 & 44.2 \\
\hline $\mathbf{3}$ & 53.3 & 43.1 \\
\hline $\mathbf{4}$ & 35.9 & 25.3 \\
\hline $\mathbf{5}$ & 77.7 & 37.8 \\
\hline $\mathbf{6}$ & 11.8 & 8.0 \\
\hline $\mathbf{7}$ & 135.0 & 135.0 \\
\hline $\mathbf{8}$ & 54.4 & 54.4 \\
\hline $\mathbf{9}$ & 136.4 & 26.9 \\
\hline $\mathbf{1 0}$ & 47.1 & 30.7 \\
\hline$\Sigma$ & $\mathbf{1 , 1 9 8 . 2}$ & $\mathbf{5 3 9 . 4}$ \\
\hline
\end{tabular}

gravel area is. After active gravel extraction, the river washed out the bank from the side of the extraction and changed its course (2017), despite whicht the gravel was extracted from the inside of the meander, where erosion is usually insignificant. This is just one of numerous examples observed for the Stryi River.

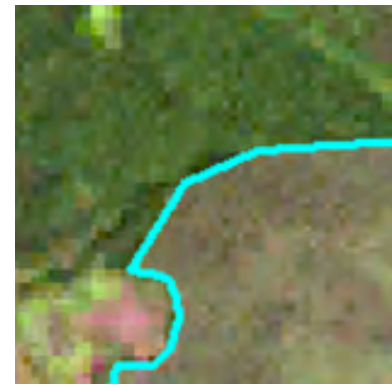

a)

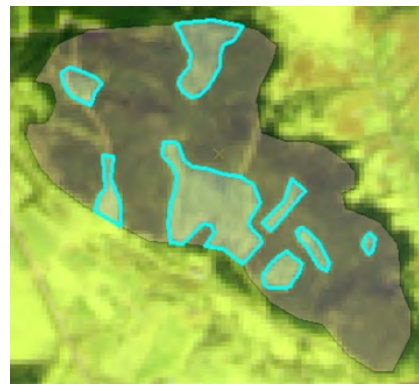

b)

Fig. 8. Enlarged fragment of site No. 9 on satellite images of 2000 (a) and 2020 (b)

Thus, remote sensing data make it possible to determine the quantitative characteristics of deforestation and to identify the sites of gravel and sand material extraction, which lead to changes in the riverbed associated with environmental threats.

\section{Conclusions}

In order to study the stability of the PreCarpathian rivers and the factors impacting rivers within the region, a methodology for long-term riverbed processes monitoring has been proposed. It consists in using topographic maps of different times, satellite images obtained with different spatial resolution, geological, soil and other special maps then processed by means of GIS systems.

Features of the hydrological regime of the rightbank tributaries of the Dniester, Stryi, Limnitsia, Bys-

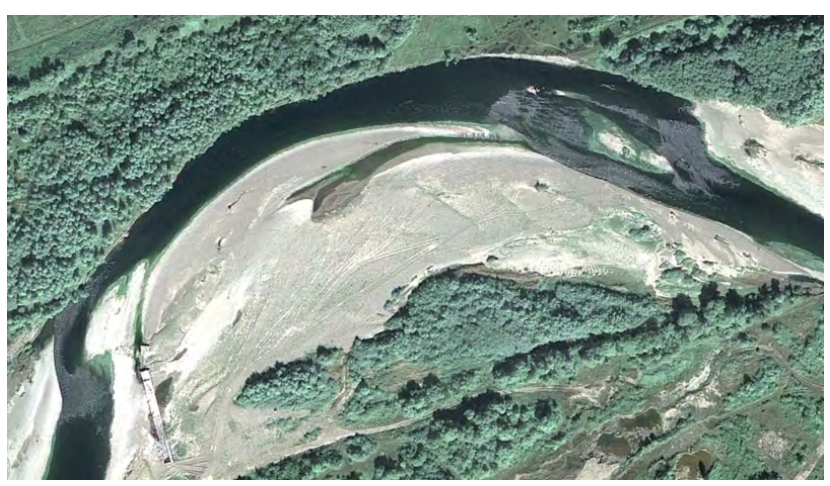

a)

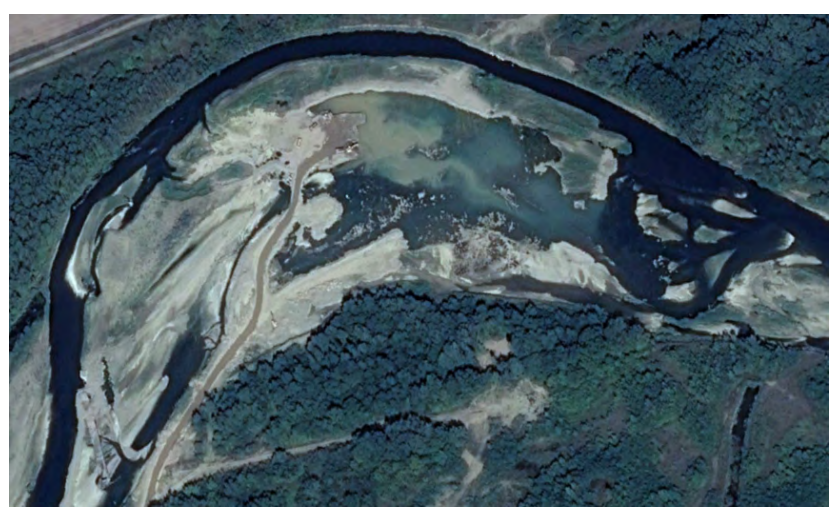

b)

Fig. 9. Fragment of the Stryi River channel before (a, 2009) and after (b, 2017) significant removal of gravel

trytsia and other rivers flowing in the Carpathians and Pre-Carpathian region are associated with the geological and sedimentological structures of the Skybovi Carpathians and the UCF. The tectonic structure also influenced the hydrological regime of the rivers, neotectonic movements resulted in a block-like structure of the outer zone of the UCF, intersected by a number of large and small disturbances. This fact determines the high erosion-denudation potential of the relief, active development of erosion and landslide processes.

Based on the results of processing topographic maps and satellite images, it has been established that the nature of the Stryi River channel indicates three different parts in terms of displacement values: the channel flows in the mountainous part without significant displacements; the second part is multi-braided river channel; the third indicates an unstable character, significant meandering, intertwining, and the formation of buttes. The maximum displacements in the mouth part reach up to $1,350 \mathrm{~m}$.

The research study testifies that due to lithological features and significant ecological disturbances the river channel has significant horizontal displacements near Stryi city and at the river mouth.

The anthropogenic factors influencing channel processes include deforestation and the extraction of sand-gravel materials. Deforestation leads to a several-fold increase in surface water runoff during 
floods. Experimental study has shown that the area of deforestation within the Stryi river basin near the town of Turka amounts to 540 ha during a 20 -year period (2000-2020).

Processing of Earth remote sensing materials using GIS technologies makes it possible to determine hydrological and ecological disturbances associated with deforestation and extraction of gravel-sand materials.

\section{References}

Ali, A., Riaz, S., \& Iqbal S. (2014). Deforestation and its impacts on climate change an overview of Pakistan. Papers on Global Change IGBP.

Bayrak H. (2011). Suchasni ruslovi protsesy i dynamika rusla r.Tysy na dilyantsi peretynu VyhorlatHutyns'koho vulkanichnoho pasma. [Modern channel processes and dynamics of the Tisza riverbed at the intersection of the Vygorlat-Gutyn volcanic ridge]. Fizychna heohrafiya ta heomorfolohiya. 62. 45-54. (in Ukrainian).

Beighley, R. E., Eggert, K. G., Dunne, T., He, Y., Gummadi, V., \& Verdin K. L. (2009). Simulating hydrologic and hydraulic processes throughout the Amazon River Basin. Hydrological Processes: An International Journal, 23(8), 1221-1235.

Bradshaw, C. J., Sodhi, N. S., PEH, K. S. H., \& Brook B.W. (2007). Global evidence that deforestation amplifies flood risk and severity in the developing world. Global Change Biology, 13(11), 23792395.

Bubniak I., Bubniak A. (1997). Pro pryrodu Stryiskoho yurskoho prohynu. [On the nature of the Stryi Jurassic depression]. Pratsi NTSh. Heolohiia, heofizyka, khemiia, biokhemiia, materialoznavstvo, mekhanika materialiv. 69-72. (in Ukrainian).

Buffington, J. M., Woodsmith, R. D., Booth, D. B., \& Montgomery D. R. (2003). Fluvial processes in Puget Sound rivers and the Pacific Northwest. Restoration of Puget Sound Rivers, 46-78.

Burshtynska Kh., Shevchuk V., Babushka A., Tretyak S., Halochkin M. (2018). Monitoring of the riverbed of river Dniester using remote sensing data and GIS technologies. 25th Anniversary Conference Geographic Information Systems Conference and Exhibition "GIS ODYSSEY 2018", 64-73.

Burshtynska Kh., Zayac I., Tretyak S., Halochkin M. (2017). Monitoring of the riverbed of river Dniester of the Carpathian Region using GIS technologies. Archiwum Fotogrametrii, Kartografii i Teledetekcji, vol. 29. 25-36.

Burshtynska, K. V., Babushka, A. V., Bubniak, I. M., Babiy, L. V., \& Tretyak S. K. (2019). Influence of geological structures on the nature of riverbed displacements for the rivers of the Dnister basin upper part. Heodynamika: scientific journal, 2 (27), 24-38.
Burshtynska, K., Polishchuk, B., \& Madyar J. (2014). The definition of the area of felling forests by high resolution satellite images. Geomatics, Landmanagement and Landscape. 3. 43-54.

Burshtynska, K., Shevchuk, V., Tretyak, S., \& Vekliuk V. (2016). Monitoring of the riverbeds of rivers Dniester and Tisza of the Carpathian region. International Archives of the Photogrammetry, Remote Sensing \& Spatial Information Sciences, 41.

Burshtynska, Kh., Tretiak, S., \& Halochkin M. (2017). Doslidzhennia horyzontalnykh zmishchen rusla richky Dnister z vykorystanniam danykh DZZ ta HIS-tekhnolohii. [Investigation of horizontal displacements of the Dniester riverbed using remote sensing data and GIS technologies]. Heodynamika 2(23). 14-24. (in Ukrainian).

Buys P. (2007). At loggerheads?: agricultural expansion, poverty reduction, and environment in the tropical forests. World Bank Publications.

Guneralp I. (2011). Channel avulsion processes on the lower Brazos river, Texas/Guneralp I., Billy U. Hales, Anthony M. Filippi. TWDB Final Report, 904830968, 88.

Havrylyshyn, V. Y., Pasternak, S. Y., \& Rozumeiko S.V. (1991). Stratyhrafycheskye podrazdelenyia melovykh otlozhenyi platformennoi chasti zapada Ukrainy. [Stratigraphic subdivisions of Cretaceous deposits of the platform part of the west of Ukraine]. Instytut heolohyii heokhimii horiuchykh iskopaemykh. Lvov, AN USSR. C.52. (in Russian).

Hintov, O. B., Bubniak, Y. N., Vykhot, Yu. M., Murovskaia, A. V., \& Nakapeliukh M. V. (2011). Evoljutsia napriazhenno-deformirovannoho sostoianyia i dynamyka Skybovoho pokrova Ukraynskykh Karpat. [Evolution of the stress-strain state and dynamics of the Skib cover of the Ukrainian Carpathians]. Heofyzycheskyi zhurnal. 5. 17-34. (in Russian).

Hooke J. (2006). Hydromorphological adjustment in meandering river systems and the role of flood events. IAHS PUBLICATION, 306, 127.

Horishnyi P. (2014). Horyzontalni deformatsii nyzhnoi techii rusla richky Stryi u 1896-2006 rr. [Horizontal deformation of the lower flow of the Striy riverbed in the 1896-2006 period]. Problemy heomorfolohii i paleoheohrafii Ukrainskykh Karpat i prylehlykh terytorii. Vydavnytstvo LNU imeni Ivana Franka. 68-74. (in Ukrainian).

Janicke S. (2000). Stream channel processes. Water \& Rivers Commission.

Josephat M. (2018). Deforestation in Uganda: Population increase, forests loss and climate change. Environ Risk Assess Remediat, 2(2), 46-50.

Kabal M. (2016). Rol lisiv u pidtrymtsi vodnoho balansu $\mathrm{v}$ umovakh Ukrainskykh Karpat. [The role of forests in maintaining water balance in the Ukrainian Carpathians]. Ukrainian Nature Conservation Group. (in Ukrainian). 
Kokhan S., Dorozhynskyy O., Burshtynska K., Vostokov A., Drozdivskyi O. (2020). Improved Approach to the Development of the Crop Monitoring System Based on the Use of Multi-Source Spatial Data. Journal of Ecological Engineering. 21 (7). 108-114.

Kovalchuk I. (2003). Hidroloho-heomorfolohichni protsesy v Karpatskomu regioni Ukrainy. [Hydrological and geomorphological processes in the Carpathian region of Ukraine]. Pratsi naukovoho tovarystva im. Shevchenka. T. XII: Ekolohichnyi zbirnyk. Ekolohichni problemy Karpatskoho rehionu. 101-125. (in Ukrainian).

Legg, N. T., \& Olson P. L. (2014). Channel migration processes and patterns in Western Washington: A synthesis for floodplain management and restoration. Shorelands and Environmental Assistance Program, Washington State Department of Ecology.

Li-An, C., Billa, L., \& Azari M. (2018). Anthropocene climate and landscape change that increases flood disasters. Int J Hydro, 2(4), 487-491.

Miller, J., Germanoski, D., Waltman, K., Tausch, R., \& Chambers J. (2001). Influence of late Holocene hillslope processes and landforms on modern channel dynamics in upland watersheds of central Nevada. Geomorphology, 38(3-4), 373-391.

Nakapelyukh, M., Bubniak, I., Bubniak, A., Jonckheere, R., \& Ratschbacher L. (2018). Cenozoic structural evolution, thermal history, and erosion of the Ukrainian Carpathians fold-thrust belt. Tectonophysics, 722, 197-209.

Nelson S. River Systems \& Causes of Flooding / Stephen A. Nelson (2012). Tulane University, Dept. Earth \& Environmental Sciences, 1-13.

Parpan, V. I., \& Olijnyk V. S. (2009). Pavodkorehuliuvalna rol hirskykh lisiv Karpat ta shliakhy yikh optymizatsii. [Flood-regulating role of Carpathian mountain forests and ways of their optimization]. Ekolohia ta noosferolohia. 20, 1-2. 121-127.

Rudko, H. I., \& Petryshyn V. Yu. (2014). Kharakterystyka rodovyshch valunno-hraviino-pishchanykh porid u Lvivskii oblasti ta yikh vplyv na ekolohichnyi stan pryrodnoho seredovyshcha mistsevosti. [Characteristics of boulder-gravel-sand deposits in Lviv region and their impact on the ecological state of the natural environment]. Mineralni resursy Ukrainy, (1). 39-47. (in Ukrainian).

Shevchuk, V. M., \& Burshtynska Kh. V. (2011). Metodyka monitorynhu richok na urbanizovanykh terytoriiakh. [Methods of rivers monitoring in urban areas]. Heodeziia, kartohrafiia i aerofotoznimannia. Vyp, 75. 73-82. (in Ukrainian).

Shuliarenko I. (1998). Otsinka horyzontalnykh ruslovykh deformatsii ta stiikosti rusel malykh i serednikh richok baseinu Dnipra. [Estimation of horizontal channel deformations and stability of channels of small and average rivers of the Dnieper basin]. Avtoreferat dysertatsii na zdobuttia naukovoho stupenia kandydata heohrafichnykh nauk. Kyiv.

Volosetskyi, B. I., \& Shpyrnal T. H. (2013). Doslidzhennia perenesennia hraviino-halkovykh mas u rusli r. Stryi za danymy heodezychnoho monitorynhu. [Study of gravel-pebble mass transfer in the Stryi riverbed according to geodetic monitoring data]. Heodeziia, kartohrafiia i aerofotoznimannia. Vyp. 77. 115-121. (in Ukrainian).

Yatsyk, A. V., Byshovets, L. V., \& Bohatov Ye. O. (1991). Mali richky Ukrainy: Dovidnyk. [Small rivers of Ukraine: Handbook]. Urozhai, Kyiv.

You, X. (2012). Forest and flood: aftermath of the 1998 Yangtze River flood. 